\title{
Use of response surface method for the prediction of osmo-solar drying behavior of Anamur banana rings
}

Anamur muz halkalarının osmo-solar kuruma davranışının belirlenmesi için yanıt yüzey yönteminin kullanılması

\section{Zehra YILDIZ ${ }^{1 / D}$ (D), Muhammed AKKARi²}

${ }^{1}$ Tarsus University, Faculty of Engineering, Department of Mechanical Engineering, Mersin, Turkey.

${ }^{2}$ Tarsus University, Faculty of Technology, Department of Energy Systems Engineering, Mersin, Turkey.

MAKALE BILGISI / ARTICLE INFO

Makale tarihçesi / Article history:

DOI: $10.37908 /$ mkutbd.796482

Geliş tarihi /Received:17.09.2020

Kabul tarihi/Accepted:18.12.2020

\section{Keywords:}

Drying, osmotic dehydration, osmosolar drying, solar dryer, RSM.

\footnotetext{
Corresponding author: Zehra YILDIZ
}

$\bowtie$ : zyildiz@tarsus.edu.tr
ÖZET / A B STR ACT

Atıf / Citation: Yıldız Z, Akkari M (2021) Use of response surface method for the prediction of osmo-solar drying behavior of Anamur banana rings. MKU. Tar. Bil. Derg. 26(1) : 183-192. DOI: 10.37908/mkutbd.796482

\section{INTRODUCTION}

It is a significant problem for the food sector that the rest of the products after consuming fresh fruit and vegetables to be preserved for a long time. The storage of fresh food not to be decomposed for a long time are various drying techniques such as hot air drying, vacuum drying, solar drying, microwave drying and freeze-drying. The oldest and most common traditional food preservation method known to humankind for drying food items is leaving them under the sun. However, this method takes a lot of time and the total product quality is not guaranteed by the impurities that may come from outside sources. To solve these problems, many different dryers have been developed over the decades. However, drying the main hurdle using mechanical dryers is that these dryers are not economical than drying under the sun due mainly to energy costs. The drying process carried out in solar tray dryers could improve the quality of the food product better in costeffectiveness, texture (crispiness, fluffiness and porous), and attaining long shelf life drying food products under the sun. Also, drying in solar tray dryers shortens the drying time and the drying potential substantially increases (Aboud, 2013; Eren and Ertekin, 2007; İspir and Toğrul, 2009; Ochoa et al., 2006). 
Osmotic processes can be obtained, improving the food product's quality and a better outlook in the dried products. To increase the efficiency of the drying process in solar drying can be considered to use together with osmotic dehydration. To drying of foods such as bananas, which are sensitive to high temperature, can be applied together with osmotic dehydrations and solar drying. With the hybrid technique, also called solar drying, is removed as a part of the moisture in food by the osmotic dehydration and the rest of the moisture by solar drying and so the low-cost, crispy, fluffy, porous, and a long shelf-life product can be obtained. This type of drying process occurs at low temperatures; thus, heat damage is less than other drying methods such as oxidation and the flavorings change in food. The dried products, it gains a porous structure that the dehumidifying capacity is high. On the other hand, the osmotic dehydration pretreatment shortens the drying time and the dryer potential increases. Pre-treatments to be applied before the drying process impacts dried product quality and operating costs are significant. The studies related to implementing osmotic dehydration as a drying pretreatment technique become attractive (Lombard et al., 2008; Bórquez et al., 2010; Torringa et al., 2001).

Food products were pre-dried with osmotic dehydration and then in the solar tray dryer, it was determined predrying had an effect on solar drying. Osmotic dehydration provided to remove moisture content from texture. Drying process load is decreased though drying is less short time by the osmotic dehydration pretreatment. It is shown that the dried products are determined to increase rehydration and organoleptic properties such as color, texture and aroma after the osmotic dehydration (Eren, 2004; Erünal 2010).

On an industrial scale, the solar drying process should be made modeling process parameters for production at a lower cost. For this reason, it was investigated that the banana slice of solar drying in Mersin, where there is high sun potentiality, was dried by solar tray dryer under drying conditions. Mersin is very important for fruit and vegetable production, and more than half of the total vegetable and fruit production, especially banana in Turkey, is cultivated in the Mersin region. For this reason, solar dryers will be of great benefit to farmers in the agricultural sector in areas with high solar potential but high humidity levels such as Mersin. Domestic banana production is carried out in Antalya and Mersin. Mersin meets $73 \%$ of banana production. Bananas are produced in Aydıncık, Yenişehir, Toroslar, Tarsus, Akdeniz, and Silifke districts of Mersin as well as Anamur,
Bozyazı and Erdemli districts. The fourth most produced fruit in Mersin is banana and it is a very important food product in the development of agriculture in the region (Subaşı et al. 2016; Akkova and Güven, 2018). Banana is a very perishable fruit and preserving it for a long time is an important problem. The initial moisture content of the banana is $80 \%$, and its shelf life can be extended when it is dried to a moisture content of $15 \%$. The air temperature required for drying bananas is high, $70^{\circ} \mathrm{C}$ (Ertekin and Yaldız, 1998).

Osmotic dehydration experiments were made with different concentration solutions in the shaking water bath. Solar drying experiments were performed in the solar tray dryer after osmotic dehydration treatment. For predicting effects of the parameters such as the osmotic dehydration time, drying time, kind of solutions and concentration of solutions on the water loss and the shrinkage ratio, one approach could identify an inputoutput relationship between the involved variables based on the experimental measurements.

As one of the optimization methods widely used in food science and technology, RSM is used more frequently in cases where many process parameters are effective on the performance of the process and the product's quality characteristics. RSM is a dynamic optimization method and examines many variables that simultaneously and together affect the system's objective function. RSM was used in most of these drying studies. For the optimization of the drying process in a solar tray dryer, the response surface method was used, experiments were done according to the experimental design determined by this method, a mathematical model was obtained according to the results of the experiment, and optimization was made on this model (Ertekin and Sultanoğlu, 2000: Mitra and Meda, 2009: Eren and Ertekin, 2007: Eren, 2004: Yıldız and Sarımeşeli, 2016). Osmosolar drying process of banana is modeling and optimization of the process conditions. Firstly, the model structure based on input and output data during the osmosolar drying process was developed using RSM. Estimation results showed that a good modeling design was made using RSM. In this study, we employed an RSM method to analyze and model the drying process to improve prediction accuracy. The RSM was used to determine the optimum operating conditions for water loss, yellow color change and the shrinkage ratio during the osmosolar dehydration drying of banana.

\section{MATERIALS and METHODS}

Drying heat was carried out with natural heat convection in the solar tray dryer shown in Figure 1, and the effect 
of drying conditions on the drying process was determined. Solar tray dryer consisted of a solar collector and solar cabinet with a tray to dry. There were five steel trays with holes in the solar cabinet. There was a cover on the dryer's back to allow these trays to be placed in the dryer.

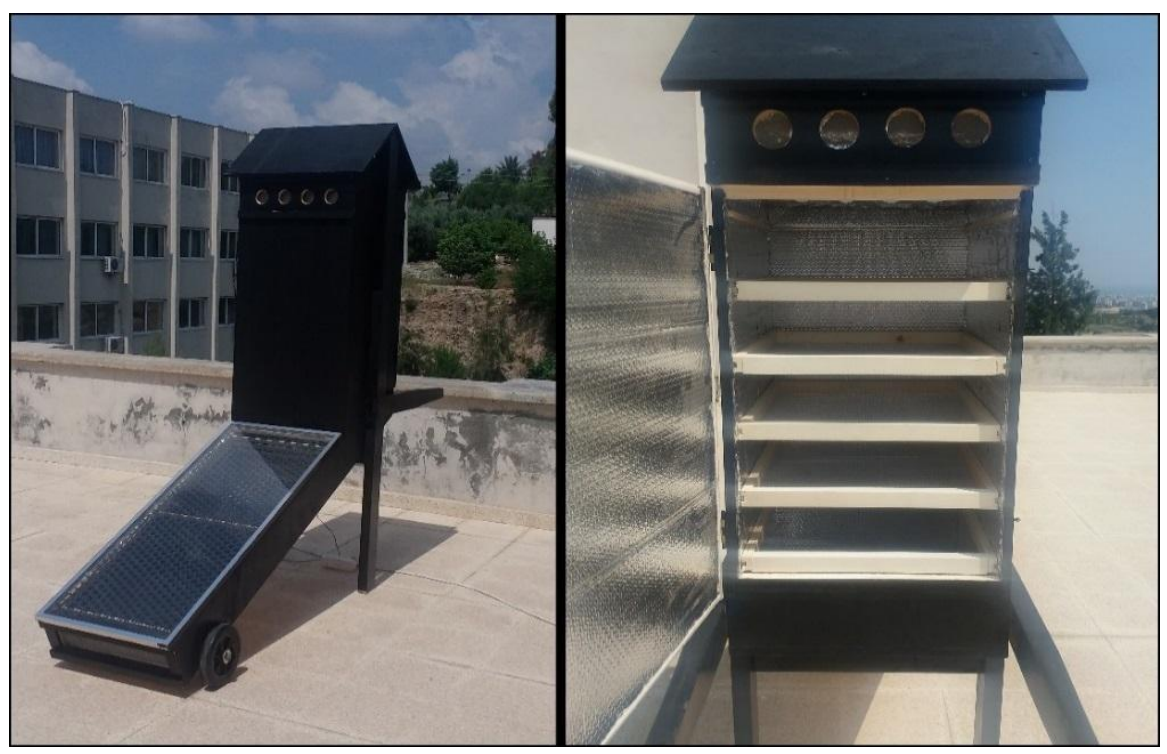

Figure 1. Solar tray dryer

The solar air heater was used to supply the required hot air to the cabinet. The solar collector consists of a wooden case, three black painted perforated plates placed on top of each other with $1 \mathrm{~cm}$ spacing to collect sunlight, and a glass panel covering the top of the collector. The sun rays were collected at the collector surface and converted to heat energy, and the heat was then transferred to the air in the solar cabinet by natural convection. The hot air is first dried through the solar cabinet, then through the tray where the products are placed, the moisture air is purged from the outlet vent, and that the drying process is completed.
The fresh organic banana (Anamur) dried by using a solar tray dryer in Mersin, Turkey. Fresh bananas were obtained from a local market, sorted visually for size, maturity level and physical damage. The product was stored at $4^{\circ} \mathrm{C}$ under refrigeration until used. The average moisture content of the samples used was found to be $88.2 \%$ on a wet basis. Banana samples peeled and sliced to a half circular shape form according to RSM experiment conditions as five apple samples in the slice thickness of $2 \mathrm{~mm}, 3 \mathrm{~mm}, 4 \mathrm{~mm}, 5 \mathrm{~mm}$ and $6 \mathrm{~mm}$. Table 1 shows the independent variables with their codes and actual levels employed in the design matrix.

Table 1.Codes and actual levels of the independent variables for design of experiment

\begin{tabular}{|c|c|c|c|c|c|c|}
\hline \multirow{2}{*}{ Independent Variables } & \multirow{2}{*}{ Symbols } & \multicolumn{5}{|c|}{ Codes levels } \\
\hline & & -2 & -1 & 0 & 1 & +2 \\
\hline Sucrose concentration (\%w/v) & $A$ & 0 & 10 & 20 & 30 & 40 \\
\hline Slice thickness (mm) & B & 2 & 3 & 4 & 5 & 6 \\
\hline Solar Drying Time (min) & $\mathrm{C}$ & 30 & 60 & 90 & 120 & 150 \\
\hline İmmerse Time (min) & $\mathrm{D}$ & 60 & 120 & 240 & 360 & 480 \\
\hline
\end{tabular}

Banana samples peeled and sliced to a ring shape of the thickness and then immersed in a different sucrose solution from $30 \mathrm{~min}$ to $150 \mathrm{~min}$ at room temperature, then each sample was placed on the tray. As the osmotic agent, sucrose having $99.9 \%$ purity was used. Then an osmotic solution was prepared by mixing the sucrose with a proper amount of distilled water.
Banana rings were first immersed in sucrose solution and then dried in a solar dryer. The air coming out of the collector that collects the solar radiation is transported to the drying trays by natural convection, then the energy as the air rises, the temperature decreases and goes out of the dryer chimney. Because the temperature 
in the first tray was higher than the top trays, the solar drying was carried out on the first tray.

Banana samples were removed from the solar dryer during the drying period, and the water loss, the shrinkage ratio and yellow color change were determined. These experiments replicated five samples in the $100 \mathrm{~g}$ total apple slices to obtain a reasonable average. The water loss and shrinkage ratio were calculated according to the following equations (1) and (2) (Pandya and Yadav, 2014; Askari et al., 2008).

Water Loss $=\frac{M_{0}-M_{t}}{M o}$

Shrinkage Ratio $=\frac{D_{0}-D_{t}}{D_{0}}$

where $M_{0}$ and $M_{t}$ are the sample mass $(g), D_{0}$ and $D_{t}$ are the sample diameter $(\mathrm{mm})$ at the beginning and at time $t$, respectively.

To prevent the banana rings from browning due to oxidation and to reduce the drying time, the banana rings were first immersed in different solutions at the determined concentrations. Color value $b$ gives information about the blue-yellow colors. The positive value of $b$ denotes the yellow and the negative value of the blue color. Banana rings are white-yellow and become yellow-brown in time. Therefore, $b$ values for banana are important in color analysis (Yıldız et al. 2015). Color measurement was made three times and the average value was taken. The yellow color change in $b$ is calculated using the equation below. The color parameter $b$ of the banana rings before and after drying was determined with the colorimeter software of Lab Tools. The $b_{0}$ indicates the yellow color parameter of fresh banana rings and $\mathrm{b}$ after the drying period (Askari et al. 2008).

$\frac{\Delta b}{b_{0}}=\frac{b_{0}-b}{b_{0}}$

\section{RESULTS and DISCUSSION}

The independent variables selected for the models were the influence of drying conditions (solution concentration, osmotic dehydration time, solar drying time and slice thickness) and come out drying performance values for the water loss (WL), shrinkage ratio $(S R)$ and yellow color change $(C C)$. The response was selected by $Y_{W L}, Y_{S R}$ and $Y_{C C}$. A solution concentration (\%w/w 2.5-10), B slice thickness (2-6 mm), C solar drying time (60-300 $\mathrm{min}$ ), and D osmotic dehydration time (30$90 \mathrm{~min}$ ) were chosen independent variables as the osmosolar drying conditions.

The results of the experiments in the design expert are shown in Table 2. Based on the experimental response, $Y_{W L}$ produced by the water ratio ranged from 0.044 to $0.805, Y_{c c}$ produced by yellow color change ranged from 0.011 to 0.818 , and $Y_{S R}$ produced by the shrinkage ratio ranged from 0.024 to 0.263 . Standard 21 had a minimum for the water loss, the yellow color change and shrinkage ratio. The lowest yields of water loss, yellow color change and shrinkage ratio were $0.044,0.011$ and 0.024 , respectively, and were obtained after \% 20 sucrose solution concentration, $4 \mathrm{~mm}$ slice thickness, without solar drying and 90 min osmotic dehydration time. Standard no5 had the maximum for the water loss, standard no14 had the maximum for the yellow color change and standard no 26 had the maximum for shrinkage ratio. The highest yields of water loss and shrinkage ratio were 0.805 and 0.263 respectively. However, the lowest yields of yellow color change was 0.011 . These responses were obtained for sucrose solution concentration $\% 10$ to $30 \mathrm{~g}$, for the banana slice thickness from 3 to $4 \mathrm{~mm}$, for solar drying time from 0 to $360 \mathrm{~min}$ and for osmotic dehydration time from 60 to $150 \mathrm{~min}$.

Table 2. Four-level the experimental responses of dependent variable 


\begin{tabular}{|c|c|c|c|c|c|c|c|}
\hline Std No & $A$ & B & $C$ & $\mathrm{D}$ & $Y_{W L}$ & $Y_{c C}$ & $Y_{S R}$ \\
\hline 1 & 10 & 3 & 120 & 60 & 0.432 & 0.180 & 0.104 \\
\hline 2 & 30 & 3 & 120 & 60 & 0.400 & 0.114 & 0.101 \\
\hline 3 & 10 & 5 & 120 & 60 & 0.217 & 0.064 & 0.069 \\
\hline 4 & 30 & 5 & 120 & 60 & 0.224 & 0.267 & 0.060 \\
\hline 5 & 10 & 3 & 360 & 60 & 0.805 & 0.410 & 0.151 \\
\hline 6 & 30 & 3 & 360 & 60 & 0.766 & 0.390 & 0.112 \\
\hline 7 & 10 & 5 & 360 & 60 & 0.771 & 0.288 & 0.236 \\
\hline 8 & 30 & 5 & 360 & 60 & 0.707 & 0.372 & 0.261 \\
\hline 9 & 10 & 3 & 120 & 120 & 0.428 & 0.249 & 0.126 \\
\hline 10 & 30 & 3 & 120 & 120 & 0.339 & 0.276 & 0.102 \\
\hline 11 & 10 & 5 & 120 & 120 & 0.227 & 0.186 & 0.126 \\
\hline 12 & 30 & 5 & 120 & 120 & 0.221 & 0.239 & 0.130 \\
\hline 13 & 10 & 3 & 360 & 120 & 0.780 & 0.737 & 0.168 \\
\hline 14 & 30 & 3 & 360 & 120 & 0.698 & 0.818 & 0.128 \\
\hline 15 & 10 & 5 & 360 & 120 & 0.679 & 0.633 & 0.190 \\
\hline 16 & 30 & 5 & 360 & 120 & 0.509 & 0.387 & 0.130 \\
\hline 17 & 0 & 4 & 240 & 90 & 0.776 & 0.363 & 0.150 \\
\hline 18 & 40 & 4 & 240 & 90 & 0.563 & 0.391 & 0.150 \\
\hline 19 & 20 & 2 & 240 & 90 & 0.739 & 0.422 & 0.125 \\
\hline 20 & 20 & 6 & 240 & 90 & 0.533 & 0.245 & 0.161 \\
\hline 21 & 20 & 4 & 0 & 90 & 0.044 & 0.011 & 0.024 \\
\hline 22 & 20 & 4 & 480 & 90 & 0.694 & 0.789 & 0.129 \\
\hline 23 & 20 & 4 & 240 & 30 & 0.449 & 0.252 & 0.165 \\
\hline 24 & 20 & 4 & 240 & 150 & 0.426 & 0.350 & 0.207 \\
\hline 25 & 20 & 4 & 240 & 90 & 0.627 & 0.221 & 0.256 \\
\hline 26 & 20 & 4 & 240 & 90 & 0.636 & 0.260 & 0.263 \\
\hline 27 & 20 & 4 & 240 & 90 & 0.658 & 0.253 & 0.232 \\
\hline 28 & 20 & 4 & 240 & 90 & 0.636 & 0.219 & 0.262 \\
\hline 29 & 20 & 4 & 240 & 90 & 0.668 & 0.235 & 0.253 \\
\hline 30 & 20 & 4 & 240 & 90 & 0.680 & 0.248 & 0.263 \\
\hline
\end{tabular}

The significance of each coefficient and their interactions was shown in ANOVA analysis. ANOVA results of the models are shown in Table 3 . ANOVA suggests the model be significant at $P<0.0001$. The $P$-values used as a tool to check the significance of each of the coefficients in turn indicate the pattern of interactions between the variables. A smaller value of $P$ was more significant to the corresponding coefficient. Values greater than 0.1000 indicate the model terms are not significant. ANOVA results indicating a good model performance (with an $\mathrm{R}^{2}$ value of 0.979 and an $F$ value of 31.431 for water loss, with an $R^{2}$ value of 0.920 and $F$ value of 3.123 for yellow Table 3. ANOVA of the regression parameters for RSM color change and with an $R^{2}$ value of 0.930 and an $F$ value of 32.82 for shrinkage ratio) among linear, quadratic, cross-product, and total model. The $R^{2}$ is one of the measures of the degree of fit of a model. The model $R^{2}$ values of 0.979 (for water loss), 0.920 (for yellow color change) and 0.930 (for shrinkage ratio) can be attributed to the independent variables. It is a quadratic model that is the best model for water loss, shrinkage ratio and yellow color change. The model is selected for the highest order polynomial where the additional terms are significant. 


\begin{tabular}{llllll}
\hline Response & Regression & $\mathrm{df}$ & $\mathrm{R}^{2}$ & $\mathrm{~F}$ value & $\operatorname{Pr}>\mathrm{F}$ \\
\hline $\mathrm{WL}$ & Linear & 4 & 0.785 & 22.862 & $<0.0001$ \\
& Cross-product & 6 & 0.802 & 0.262 & 0.948 \\
& Quadratic & 4 & 0.979 & 31.431 & $<0.0001$ \\
& Cubic & 8 & 0.998 & 6.760 & 0.0103 \\
& Residual & 7 & & & \\
TC & 30 & & & \\
& Lotal & 4 & 0.769 & 20.777 & $<0.0001$ \\
& Linear & 6 & 0.854 & 1.834 & 0.146 \\
& Cross-product & 4 & 0.920 & 3.123 & 0.0468 \\
& Quadratic & 8 & 0.997 & 19.717 & 0.000383 \\
SR & Cubic & 7 & & & \\
& Residual & 30 & & & \\
& Total & 4 & 0.221 & 1.776 & 0.165 \\
& Linear & 6 & 0.321 & 0.464 & 0.826 \\
& Cross-product & 4 & 0.930 & 32.820 & $<0.0001$ \\
& Quadratic & 8 & 0.993 & 7.922 & 0.00654 \\
& Cubic & 7 & & & \\
\hline
\end{tabular}

ANOVA of the regression model for the $Y_{M L}-Y_{D R}-Y_{S R}$ response established that the model was significant due to a very low probability value ( $\mathrm{P}$ model $>\mathrm{F}-0.001$ ) ANOVA (F-test) for the model explained the response of the dependent variable. The regression coefficients, along with the corresponding P-values, for the model of production water loss, yellow color change and shrinkage ratio are described by ANOVA. Values of "Prob $>F^{\prime \prime}$ less than 0.0500 indicate model terms are significant. In this case, $A, B, C, D, C^{2}, D^{2}$ are significant model terms for water loss. $B, C, D, A^{2}, C^{2}, C D$ are significant model terms for yellow color change and $B, C$, $A^{2}, B^{2}, C^{2}, D^{2}, B C, C D$ are significant model terms for shrinkage ratio. Values greater than 0.1000 indicate the model terms are not significant. If there are many insignificant model terms that do not count those required to support hierarchy, model reduction may improve the model.

Table 4. ANOVA for the model on responses

\begin{tabular}{lllll}
\hline Water Loss & \multicolumn{3}{l}{} \\
\hline Source & Sum of Squares & $\mathrm{df}$ & $\mathrm{F}$ & $\mathrm{P}>\mathrm{F}$ \\
\hline Model & 1.24 & 14 & 49.6 & $<0.0001$ \\
$\mathrm{~A}$ & 0.0340 & 1 & 19.1 & 0.000551 \\
$\mathrm{~B}$ & 0.0943 & 1 & 53.0 & $<0.0001$ \\
$\mathrm{C}$ & 0.854 & 1 & 480 & $<0.0001$ \\
$\mathrm{D}$ & 0.00988 & 1 & 5.55 & 0.0325 \\
$\mathrm{~A}^{2}$ & $4.01 \mathrm{E}-006$ & 1 & 0.00226 & 0.963 \\
$\mathrm{~B}^{2}$ & 0.00170 & 1 & 0.955 & 0.344 \\
$\mathrm{C}^{2}$ & 0.153 & 1 & 85.9 & $<0.0001$ \\
$\mathrm{D}^{2}$ & 0.0907 & 1 & 51.0 & $<0.0001$ \\
$\mathrm{AB}$ & $3.88 \mathrm{E}-006$ & 1 & 0.00218 & 0.963 \\
$\mathrm{AC}$ & 0.00347 & 1 & 1.95 & 0.183 \\
$\mathrm{AD}$ & 0.00299 & 1 & 1.68 & 0.214 \\
$\mathrm{BC}$ & 0.00666 & 1 & 3.74 & 0.0722 \\
$\mathrm{BD}$ & 0.000987 & 1 & 0.554 & 0.0734 \\
CD & 0.00660 & 1 & 3.71 & \\
Residual & 0.0267 & 15 & & \\
Continuing Table & 4. & & &
\end{tabular}




\begin{tabular}{|c|c|c|c|c|}
\hline Lack of Fit & 0.0256 & 10 & 11.3 & 0.00771 \\
\hline Pure Error & 0.00113 & 5 & & \\
\hline $\begin{array}{l}\text { Cor Total } \\
\mathrm{R}^{2}=0.979\end{array}$ & & 29 & & \\
\hline \multicolumn{5}{|c|}{ Shrinkage Ratio } \\
\hline Source & Sum of Squares & df & $\mathrm{F}$ & $P>F$ \\
\hline Model & 0.997455 & 14 & 12.33962 & $<0.0001$ \\
\hline$A$ & 0.001215 & 1 & 0.210464 & 0.653 \\
\hline B & 0.049488 & 1 & 8.571097 & 0.0104 \\
\hline C & 0.671366 & 1 & 116.2776 & $<0.0001$ \\
\hline$D$ & 0.111305 & 1 & 19.27746 & 0.000527 \\
\hline$A^{2}$ & 0.031873 & 1 & 5.520254 & 0.0329 \\
\hline$B^{2}$ & 0.014721 & 1 & 2.549674 & 0.131 \\
\hline$C^{2}$ & 0.043521 & 1 & 7.537602 & 0.0150 \\
\hline$D^{2}$ & 0.006193 & 1 & 1.072535 & 0.317 \\
\hline$A B$ & 0.000317 & 1 & 0.054863 & 0.818 \\
\hline$A C$ & 0.006333 & 1 & 1.096874 & 0.312 \\
\hline$A D$ & 0.005166 & 1 & 0.894789 & 0.359 \\
\hline BC & 0.023389 & 1 & 4.050908 & 0.0625 \\
\hline $\mathrm{BD}$ & 0.017563 & 1 & 3.041819 & 0.102 \\
\hline$C D$ & 0.039176 & 1 & 6.785181 & 0.0199 \\
\hline Residual & 0.086607 & 15 & & \\
\hline Lack of Fit & 0.08515 & 10 & 29.21433 & 0.000821 \\
\hline Pure Error & 0.001457 & 5 & & \\
\hline $\begin{array}{l}\text { Cor Total } \\
\mathrm{R}^{2}=0.930\end{array}$ & 1.084062 & 29 & & \\
\hline \multicolumn{5}{|c|}{ Yellow color change } \\
\hline Source & Sum of Squares & $d f$ & $\mathrm{~F}$ & $P>F$ \\
\hline Model & 0.122136 & 14 & 14.31116 & $<0.0001$ \\
\hline A & 0.000904 & 1 & 1.483129 & 0.242 \\
\hline B & 0.003334 & 1 & 5.469837 & 0.0336 \\
\hline C & 0.024479 & 1 & 40.15562 & $<0.0001$ \\
\hline $\mathrm{D}$ & 0.000327 & 1 & 0.53581 & 0.475 \\
\hline$A^{2}$ & 0.019815 & 1 & 32.50581 & $<0.0001$ \\
\hline$B^{2}$ & 0.022546 & 1 & 36.98563 & $<0.0001$ \\
\hline$C^{2}$ & 0.056068 & 1 & 91.97512 & $<0.0001$ \\
\hline$D^{2}$ & 0.008785 & 1 & 14.41068 & 0.00176 \\
\hline$A B$ & 0.000277 & 1 & 0.454864 & 0.510 \\
\hline$A C$ & 0.000418 & 1 & 0.685748 & 0.421 \\
\hline$A D$ & 0.000537 & 1 & 0.880179 & 0.363 \\
\hline $\mathrm{BC}$ & 0.005762 & 1 & 9.452622 & 0.00771 \\
\hline BD & 0.000696 & 1 & 1.141067 & 0.302 \\
\hline$C D$ & 0.005374 & 1 & 8.815898 & 0.00955 \\
\hline Residual & 0.009144 & 15 & & \\
\hline Lack of Fit & 0.009144 & 10 & & \\
\hline Pure Error & 0 & 5 & & \\
\hline $\begin{array}{l}\text { Cor Total } \\
\mathrm{R}^{2}=0.920\end{array}$ & 0.13128 & 29 & & \\
\hline
\end{tabular}


The corresponding second-order models in coded variables were assembled for each response. The sucrose solution concentration has an inversely linear effect on water loss and shrinkage ratio. The banana slice thickness and osmotic dehydration time had a negative effect on the reduction of water loss; on the other hand, a positive effect on the shrinkage ratio and yellow color change. The solar drying time has a linear effect on water loss, shrinkage ratio and yellow color change. Therefore, the water loss, yellow color change and shrinkage ratio of banana slices increased with the increase of the solar drying time. As drying proceeds, water loss and shrinkage ratio increase the reason for increasing transport. The response surfaces show a similar trend for both of them, which indicates a correlation among responses.

All the variables had a significant effect on the increase of the yellow color change. Drying at high temperature or long duration could cause browning which is the result of amino acid and sugar reactions at lower moisture contents. Color changes occur at low moisture contents, during the second falling rate period of low fat banana drying. It had more effect on color changes at low moisture contents than high moisture contents (Hatami et al. 2017).

The solar drying time has only a positive effect on water loss. The moisture diffusion and surface water evaporation rates from the food matrix to increased drying air temperature between the drying air and the food by convection. Thus, it increased moisture loss (Nwakuba et al. 2018). Similar results have been reported by Abano et al (2014) for tomato slices; Cakir (2015) for red pepper; Nwakuba et al (2018) for okra slices.

The sucrose solution concentration has a negative effect on the shrinkage ratio. Sucrose solution expanded to fill the pore spaces in the banana slices on solar time, which prolonged the rate of moisture removal from samples of osmotic dehydration pre-treatment. It indicates that infusion of sucrose caused plasticity of the banana slices (Abano and Sam-Amoah 2011). As the moisture content decreases in the product, the density increases. The density of the constituent solid matrix is superior to that of the extracted solvent because the solid replaces the liquid (Talla et al. 2004). It was reported that the volumetric shrinkage rate of solar drying varied with the moisture content (Heybeli and Ertekin 2007).

For example:

$\mathrm{Y}_{\mathrm{WL}}=0.657-0.0376 \mathrm{~A}-0.0627 \mathrm{~B}+0.189 \mathrm{C}-$

$0.0203 D+0.000383 A 2-0.00787 B 2-0.0747 C 2-$
$0.0575 D 2+0.000493 A B-0.0147 A C-0.0137 A D+0.0204 B C-$ $0.00785 B D-0.0203 C D$

(Eq.4)

$\mathrm{Y}_{\mathrm{CC}}=0.239+0.00712 \mathrm{~A}+0.0454 \mathrm{~B}+0.167 \mathrm{C}+0.0681 \mathrm{D}+0.0341$

$\mathrm{A} 2+0.0232 \mathrm{~B} 2+0.0398 \mathrm{C} 2+0.015 \mathrm{D} 2+0.00445 \mathrm{AB}$

$-0.0199 A C-0.0180 A D-0.0382 B C-0.0331 B D+0.0495 C D$

(Eq.5)

$\mathrm{Y}_{S R}=0.256-0.00614 \mathrm{~A}+0.0118 \mathrm{~B}+0.0319 \mathrm{C}+0.00369 \mathrm{D}-$

$0.0269 \mathrm{~A} 2-0.0287 \mathrm{~B} 2-0.0452 \mathrm{C} 2-0.0179 \mathrm{D} 2+0.00416 \mathrm{AB}-$

$0.00511 A C-0.00579 A D+0.0190 B C-0.00659 B D-0.0183 C D$

(Eq.6)

Regression model Eq. (4-6) was obtained to determine relation on the drying conditions for water loss, drying rate and shrinkage ratio. The experiment values showed a close fit of the observed values with the predicted ones. Thus, a statistically significant multiple regression relationship between $A, B, C, D$ and the $Y_{W L}, Y_{C C}, Y_{S R}$ can be established. The quadratic model showed for $Y_{W L}, Y_{C C}$ and $Y_{S R}$ for a good fit and effectively represented the relationship among the variables selected. An F-value several times greater than the tabulated F-value shows that the model predicts the experimental results well and the effects of the estimated factors were real.

\section{CONCLUSION}

Effects of the drying conditions on water loss, yellow color change, and shrinkage ratio yield of osmosolar drying of the banana slice have been investigated. Both the water loss and shrinkage ratio have increased with increased solar drying time and immerse time. The correlation coefficient (R2) values of the water loss, shrinkage ratio and yellow color change for the RSM models were found as $0.979,0.930$ and 0.920 , respectively.

\section{ÖZET}

Amaç: Bu çalışmada muz halkaları raflı güneş enerjili kurutucu ve ozmotik dehidrasyon yöntemlerinin ikisinin bir arada kullanıldığı osmosolar dehidrasyon yöntemiyle kurutulmuştur. Kurutma koşulları yanıt yüzey yöntemi (RSM) ile modellenerek kurutma koşullarının kurutma performansına etkisi belirlenmeye çalışılmıştır.

Yöntem ve Bulgular: Muz halkaları önce sakkaroz çözeltisine daldırılmış daha sonra güneş kurutucuya konmuştur. Giriş değişkenleri olarak çözelti derişimi, dilim kalınlığı, ozmotik dehidrasyon süresi ve güneş kurutma süresi seçilmiştir. Çıkış değişkenleri olarak nem kaybı, büzülme oranı ve sarı renk değişimi seçilmiştir. Sonuçlar, hem nem kaybı hem de büzülme oranının 
güneş kurutma ve ozmotik dehidrasyon süresi ile artığını göstermiştir.

Genel Yorum: RSM korelasyon katsayıları $\left(R^{2}\right)$ sırasıyla nem kaybı, büzülme oranı ve renk değişimi için 0.979, 0.930 ve 0.920 bulunmuştur.

Çalışmanın Önemi ve Etkisi: Yüksek nem ve kurutma sıcaklığına sahip Anamur muz ozmotik dehidrasyon ve güneş kurutmanın bir bileşimi olan osmosolar dehidrasyon ile kurutulmuştur. Ozmotik dehidrasyon ön işleminin raflı güneş enerjili kurutucu ile kurutulan muz halkalarının kurutulmasında etkili olduğu bulunmuştur.

Anahtar Kelimeler: Kurutma, ozmotik dehidrasyon, güneş kurutucu, RSM.

\section{ACKNOWLEDGEMENTS}

The study was supported by Tübitak 2209-A with the 1919B011903966 project.

\section{CONFLICT OF INTEREST}

The authors declare no conflict of interest for this study.

\section{AUTHOR'S CONTRIBUTIONS}

The contribution of the authors is equal.

\section{REFERENCES}

Abano EE, Sam-Amoah LK (2011) Effects of different pretreatments on drying characteristics of banana slices. ARPN Journal of Engineering and Applied Sciences 2(3):121-129.

Abano EE, Ma H and Qu W (2014). Optimization of drying conditions for quality dried tomato slices using response surface methodology. Journal of Food Process and Preservation 38: 996-1009.

Aboud A (2013) Drying characteristic of banana rings undertaken the effect of passive shelf solar dryer and open sun drying. Pakistan Journal of Nutrition 12(3): 250-254.

Akova SB, Güven Ş (2018) Mersin Meyveciliğinde Muzun Yeri Ve Önemi. Marmara Coğrafya 37: 271-289.

Askari GR, Emam-Djomeh Z, Mousavi SM (2008) Investigation of the Effects of Microwave Treatment on the Optical Properties of Apple Rings During Drying, Drying Technology 26: 1362-1368

Bórquez RM, Canales ER, Redon JP (2010) Osmotic dehydration of raspberries with vacuum pretreatment followed by microwave-vacuum drying, Journal of Food Engineering 99(2): 121-127.
Botchkarev A (2018) Performance Metrics Error Measures in Machine Learning Regression, Forecasting and Prognostics: Properties and Typology.

Çakır M (2015). Güneş Enerjisinden Yararlanarak Tarım Ürünlerinin Kurutulması. Gazi Mühendislik Bilimleri Dergisi 1(1): 41-55.

Eren i (2004) Patateslerin osmotic dehidrasyonunun response surface metodu kullanılarak optimizasyonu. MSc Theysis. Ege University.

Eren i, Ertekin FK (2007) Optimization of osmotic dehydration of potato using response surface methodology. Journal of Food Engineering 79: 344352.

Ertekin C, Yaldız O (1998) Bazı sebze, meyve ve baharatlı bitkilerin kurutulma yöntemleri ve kullanılan güneş enerjili kurutucular. Tarımsal Mekanizasyon 18. Ulusal Kongresi.

Ertekin FK, Sultanoğlu M (2000) Modelling of mass transfer during osmotic dehydration of apples. Journal of Food Engineering 464: 243-250.

Erünal S (2010) Eriğin prunus domestica ozmotik dehidrasyon parametrelerinin ve kurumaya etkisinin incelenmesi. Yüksek lisans tezi, Afyon Kocatepe Üniversitesi.

Hatami S, Sadeghi M, Mireei SA (2017) Indirect forced solar drying of banana slices:phenomenological explanation of non-isotropic shrinkage and color changes kinetics. Internatıonal Journal of Green Energy 14(15): 1277-1283.

Heybeli N, Ertekin C (2007) Elma Dilimlerinin İnce Tabaka Halinde Kuruma Karakteristiği. Tarım Makinaları Bilimi Dergisi. 3(3): 179-187.

Ispir A, Toğrul iT (2009) Osmotic dehydration of apricot: kinetics and the effect of process parameters. Chemical Engineering Research and Design 872: 166180.

Lombard GE, Oliveira JC, Fito P, Andrés A (2008) Osmotic dehydration of pineapple as a pre-treatment for further drying. Journal of Food Engineering 852:277284.

Mitra P, Meda V (2009) Optimization of microwavevacuum drying parameters of saskatoon berries using response surface methodology. Drying Technology 27: 1089-1096.

Nwakuba NR, Chukwuezie OC, Asonye GU and Asoegwu SN (2018) Energy analysis and optimization of thin layer drying conditions of okra. Arid Zone Journal of Engineering, Technology and Environment 14: 135154. 
Ochoa-Martínez LA, García-Quintero M, Morales-Castro J, Gallegos-Infante J, Martínez-Sánchez CE, HermanLara $\mathrm{E}$ (2006) Effect of $\mathrm{CaCl}_{2}$ and convective osmotic drying on texture and preference of banana. Journal of Food Quality 29: 583-595.

Pandya R, Yadav KC (2014) Study on effect of pretreatments and microwave drying on banana chips. IOSR Journal of Agriculture and Veterinary Science IOSR-JAVS 77: 04-10.

Prakash O, Kumar A (2013) Historical review and recent trends in solar drying systems, International Journal of Green Energy 10(7): 690-738.

Subaşı OS, Seçer A, Yaşar B, Emeksiz F, Uysal O (2016) Production cost and profitability of banana in Turkey. Mediterranean Agricultural Sciences 292: 73-78.

Talla A, Puiggali JR, Jomaa W, Jannot Y (2004) Shrinkage and density evolution during drying of tropical fruits: application to banana. Journal of Food Engineering 64: 103-109.
Torringa E, Esveld E, Scheewe I, Berg R, Bartels P (2001) Osmotic dehydration as a pre-treatment before combined microwave-hot-air drying of mushrooms, Journal of Food Engineering 49(2-3): 185-191

Yıldız AK, Polatcı H, Ucun H (2015). Farklı kurutma şartlarında muz meyvesinin kurutulması ve kurutma kinetiğin yapay sinir ağları ile modellenmesi. Tarım Makineleri Bilim Dergisi 11(2): 173-178.

Yıldız Z, Sarımeşeli A (2016) Optimization of Osmotic Dehydration of Organic Red Pepper Using Response Surface Methodology. International Journal of Engineering \& Applied Sciences (IJEAS) 7: 419-33. 